\title{
CLARENCE ABIATHAR WALDO
}

\author{
BY W. H. ROEVER
}

It has been said that next to those who are directly laboring to extend and advance science, they contribute to its progress who prepare fitting aids to the young beginner and remove the difficulties in his way. The late Clarence Abiathar Waldo was thus outstanding as a contributor to scientific progress in this country. He was essentially a teacher, having once said of himself: "My greatest contribution to education has been my intimate contact with thousands of young men during their college period..... These are my intellectual children, whose ideals I have helped to form. As a teacher of men, I will be best known and remembered."

$\mathrm{He}$ was among the pioneers in mathematical organization in this country. In 1891 he became member of the New York Mathematical Society, which was reorganized in 1894 as the American Mathematical Society. He was one of the small group of mathematicians present at the Mathematical Congress at Chicago and the Colloquium at Evanston in 1893. He was active on several committees of the Society, serving with Professors Bolza and Townsend in framing a report on the requirements for the Master's Degree (this Bulletin, vol. 10, p. 380). He was also a charter member of the Mathematical Association of America, being particularly active in the Missouri Section.

Professor Waldo's mathematical interests were chiefly in applications to engineering. He was author of a Manual of Descriptive Geometry (D. C. Heath, 1888), to which the remark above concerning "fitting aids to the young beginner" was particularly applicable. He followed the practice, now too much neglected, of having the student make models of the space objects under consideration in the course. His address as retiring chairman of Section D (now M) of the American Association for the Advancement of Science on the subject The relation of mathematics to engineering (Proceedings, vol. 53 (1904)) is interesting and instructive. In the Association for the Advancement of Science he was also secretary of the council, 190304, and general secretary and editor of the Proceedings, 1904-05. He was very active in the Society for the Promotion of Engineering Education, serving as treasurer, 1900, and editor of its Proceedings, 1901-03. The Indiana Academy of Science was also fortunate in having Professor Waldo as editor of its Proceedings, 1896-98, and as president, 1898. In connection with his work in the Academy, Professor Waldo told with amusement of a bill which had been introduced in the Indiana Legislature fixing a "new and correct value of $\pi$ " as a definite rational number. The bill was being favorably considered when he heard of it, and quick action was necessary to prevent its passage. It was due to his efforts that the bill was rejected. He was a member of Sigma Xi and Phi Beta Kappa.

Other activities than those strictly scientific also claimed his interest, and attention. He was a member and president, 1890, of the Indiana 
College Association. His interest in athletics was very keen. He was arbitrator of the Chicago Conference of Colleges, 1901-12, and of the Ohio Conference of Colleges, 1903-05.

Professor Waldo received the degrees A.B. and A.M. from Wesleyan University in 1875 and 1878 , respectively, and the degree $\mathrm{Ph} . \mathrm{D}$. from Syracuse University in 1894. He spent the academic year 1882-83 in study at the universities of Leipzig and Munich.

He held the following academic positions: Instructor in Mathematics and Registrar, Wesleyan University, Conn., 1877-81; Professor of Mathematics, 1883-91, and Acting President, 1885-86, 1888-89, Rose Polytechnic Institute; Professor of Mathematics, De Pauw University, 1891-95; Head Professor of Mathematics, 1895-98, Purdue University; Professor of Mathematics, 1908-10, Thayer Professor of Mathematics and Applied Mechanics and Head of the Department of Mathematics, 1910-17, Professor Emeritus after 1917, Washington University. After leaving Washington University, he worked actively on exemption boards in New York City in 1917-18. In 1919 he was College Visitor for the Carnegie Foundation.

Professor Waldo was born in Hammond, New York, January 21, 1852. He died in Bridgeport, Conn., October 1, 1926. He married Miss Abby Wright Allen, August 2, 1881, in Stamford, Conn. He had two children, Alice Goddard and Clarence A. (deceased).

His pleasing personality and his kindly nature endeared him to all who knew him. His high ideals were built on deep religious foundations and were reflected in his daily life.

WASHINGTON UNIVERSITY 